\title{
ASSESSMENT OF THE FREQUENCY OF FOOD PRODUCTS CONSUMPTION AND DIETARY SUPPLEMENTS BY MILITARY AVIATION PERSONNEL DEPENDING ON THEIR NUTRITIONAL KNOWLEDGE
}

Agata GAŹDZIŃSKA', Marta TURCZYŃSKA'1, Paweł JAGIELSKI²

1 Laboratory of Dietetics and Obesity Treatment, Department of Psychophysiological Measurements and Human Factor Research, Military Institute of Aviation Medicine, Warsaw, Poland

2 Department of Nutrition and Drug Research, Faculty of Health Science, Jagiellonian University, Medical College, Cracow, Poland

Source of support: The research was conducted as part of the National Health Program 2016-2020 for the Ministry of National Defence.

Author's address: Agata Gaździńska, Military Institute of Aviation Medicine, ul. Krasińskiego 54/56 Street, 01-755 Warsaw, Poland, e-mail: agazdzinska@wiml.waw.pl

Introduction: Nutritional behaviour is the result of many factors, one of which is nutritional knowledge. A higher level of nutritional knowledge promotes proper nutrition, which is the main factor influencing health, nutritional status and psychophysical efficiency. The aim of the study was to determine the customary frequency of consumption of selected food products and dietary supplements by Air Force soldiers depending on their level of nutritional knowledge.

Methods: The study was carried out among 540 Air Force soldiers and 498 persons with complete data (32 women, 466 men; mean age $36.3 \pm 8.5$ years) were included in the analysis. The FFQ food consumption frequency questionnaire was used to assess the frequency of food consumption. Nutrition knowledge was assessed on the basis of 32 statements on food and nutrition.

Results: The level of nutritional knowledge depended significantly on the education and age of the respondents. In the group of the surveyed soldiers, military pilots showed the highest level of nutritional knowledge, while the lowest level was shown by engineering and aviation services. The frequency of consumption of milk and natural dairy drinks, curds, eggs, wholemeal bread, coarse groats, fruits, vegetables, oils, nuts, seeds, poultry meat,

Figures: 3 - Tables: 4 • References: 47 - Full-text PDF: http://www.pjambp.com • Copyright @ 2020 Polish Aviation Medicine Society, ul. Krasińskiego 54/56, 01-755 Warsaw, license WIML・Indexation: Index Copernicus, Polish Ministry of Science and Higher Education 
rabbit meat, honey, wine and drinks increased significantly with the increase in the level of nutritional knowledge, while the frequency of consumption of margarines in cubes, margarines in cups, animal fats and cured meats decreased. Dietary supplements such as vitamin, mineral and vitamin-mineral preparations were significantly more frequently consumed by soldiers with a higher level of nutritional knowledge.

Conclusions: 1 . On the basis of the assessment of the frequency of consumption of products, a number of abnormalities were found among the majority of the surveyed soldiers of military aviation personnel.

2. The results obtained confirm that a higher level of nutritional knowledge promotes healthy eating habits among the Air Force soldiers.

3. Food education is essential, especially among soldiers in the older age group and ground flying personnel.

Keywords: nutritional knowledge, soldiers, frequency of consumption, military aviation personnel

\section{INTRODUCTION}

Nutritional behaviour is the result of many factors, one of which is nutritional knowledge. A higher level of nutritional knowledge promotes proper nutrition, which is the main factor influencing health and psychophysical fitness, so important during military service. The majority of researchers emphasize the positive role of nutritional education in making nutritional choices $[1,6]$.

Nutrition education is a long-term, continuous process of systematically transferring knowledge about food and nutrition, based on current and proven scientific research results. It may be of institutional or popularizing nature (popularization in radio, television, press and other forms of communication) [14]. Successive acquisition and correction of knowledge in the field of proper nutrition allows to shape proper nutritional attitudes and skills which, if properly implemented, have a positive impact on health [46]. In nutritional education it is important to develop proper dietary choices and the ability to compose meals. It enables rational decision making when buying food products, acquiring the habit of reading information on product labels, choosing meals in a military canteen or restaurant during a delegation [31].

The way in which dietary needs are met is influenced by many factors related to the external environment and individual attitudes towards food and individual characteristics, including age and gender $[21,45,38,3]$. On the other hand, the characteristics of the product itself (taste, smell, texture) and its price are very important. Among the numerous causes of dietary errors, the lack of knowledge of the principles of proper nutri- tion is one of the fundamental ones [9]. Therefore, prevention activities aimed at appropriate food education in various social groups, including uniformed services, are of particular importance.

Many results of studies on the diet of the Polish population indicate the occurrence of a number of abnormalities and frequent mistakes in nutrition [16]. These include, among others: non-compliant consumption of certain groups of food products of important health significance, such as fatty marine fish, whole grain products or legumes [36,8]. The consequence of long-lasting nutritional abnormalities may be an increased risk of development of many diet-related diseases, including overweight and obesity [40], which is common in the Polish Armed Forces, including military flying personnel and cadets of the Air Force Academy [11,12].

Stress and haste that accompanies people nowadays and the growing fashion for a healthy lifestyle contribute to the increase in sales of dietary supplements [4]. Studies carried out in many centres indicate that dietary supplementation with various preparations is a common phenomenon, as daily diet is supplemented by 14 to $75 \%$ of respondents [24]. Active professional life often makes it difficult to prepare and eat properly balanced meals, most often people leading such a lifestyle accept dietary supplements - because they are concentrated foodstuffs rich in vitamins and/or minerals. This practice has its advantages, but it is also burdened with health risks [19,20,25]. Taking into account the above facts, the knowledge of the principles of rational nutrition is very important and to a large extent allows for optimal 
selection of food products without the use of dietary supplements $[3,17]$.

The aim of the study was to determine the customary frequency of consumption of selected food products, beverages and dietary supplements by Air Force soldiers depending on their level of nutritional knowledge. To the best of our knowledge, no one has ever conducted such research in a group of military aviation personnel.

\section{METHODS}

The research was carried out among 540 Air Force soldiers and 498 persons with complete data (32 women, 466 men) were included in the analysis. The mean age of the respondents was $36.3 \pm 8.5$ years (age range 19-59 years). The majority of the respondents were SIL (Engineering and Aviation Service Staff) soldiers (35\%), followed by military pilots (32\%), flight attendants (19.5\%), cadets of the Air Force Academy in Dęblin (8\%), the rest of the respondents were other ground flight attendants.

The study used a Food Frequency Questionnaire (FFQ) validated for the Polish population [28], which was modified for the purposes of the study by adding two categories of possible answers concerning the frequency of consumption, i.e. quarterly or less frequently and weekly. 8 categories of frequency of consumption were used (1 - never or almost never, 2 - once a quarter or less often, 3 - once a month or less often, 4 - several times a month, 5 - once a week, 6 - several times a week, 7 - daily, 8 - several times a day), the answers referred to the period of the last 12 months.

The FFQ questionnaire is one of the most frequently used methods for evaluating human nutrition, in addition to the 24-hour interview method and the ongoing records. In the Wadołowska's study on the validation of the questionnaire - FFQ, a high repeatability of results was found and considered to be an accurate measurement tool that can provide reliable information on the frequency and quantity of commonly consumed food [30].
Nutritional knowledge was assessed by means of an author's questionnaire containing 32 closed questions. The questions concerned mainly the principles and recommendations of rational nutrition, the sources of certain nutrients in the daily diet and their impact on health. For each of the respondents the number of correct answers was calculated. The respondents were able to score 32 points maximum.

After verification and calculation of the total score, the respondents were assigned a general assessment of the level of knowledge, according to the following criteria:

- <13 points - insufficient nutritional knowledge,

- 13-20 points - sufficient nutritional knowledge,

- >20 points - good level of nutritional knowledge.

Data analysis was performed in PS IMAGO PRO (IBM SPSS Statistics 25). Consistency of the distribution of analysed variables with the normal distribution was checked using the Shapiro-Wilk test. The significance of differences in the analysed variables between the studied groups, due to the distribution of features differing from the normal distribution, was tested with $U$ MannWhitney's or ANOVA Kruskal-Wallis' test. For all analysed parameters the significance level was adopted $(a=0.05)$.

The research was conducted in 2017 in the Military Institute of Aviation Medicine in Warsaw. Respondents expressed informed consent to participate in the study. The study was approved by the Ethics Committee which issues opinions on biomedical research at the Military Institute of Aviation Medicine in Warsaw (Decision No. 01/2018).

\section{RESULTS}

The majority of respondents were men (93.5\%), living in cities with less than 100,000 inhabitants and in large cities with more than 100,000 inhabitants (fig. 1). $68 \%$ of respondents declared that they were married, $18 \%$ that they were unmarried (fig. 2).

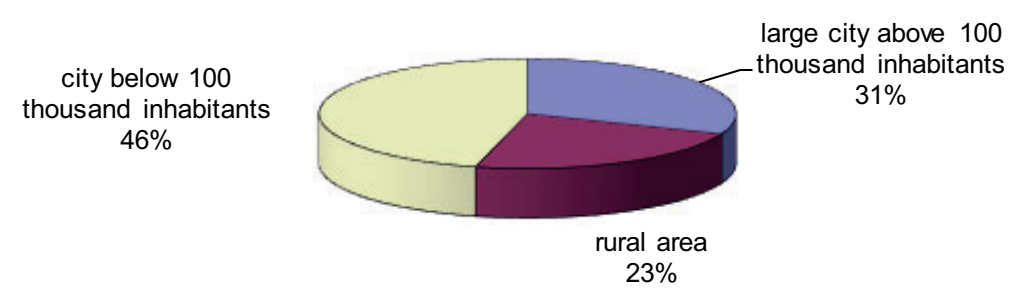

Fig. 1. Characteristics of the respondents by place of residence. 


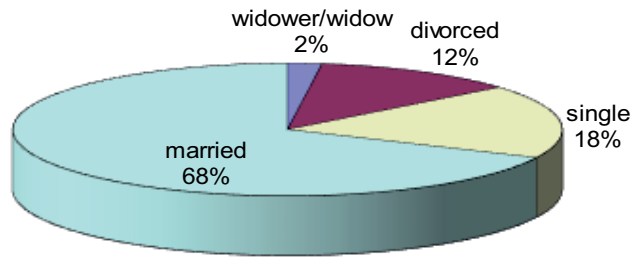

Fig. 2. Characteristics of the respondents according to their marital status.

Taking into account the education, the largest group werepeoplewith highereducation (61\%), the remaining respondents had secondary education. There were no people with vocational education in the study. Normal body weight according to BMI (Body Mass Index), according to the guidelines of the World Health Organization [44], was $35 \%$ of the examined soldiers, overweight $48 \%$ and obesity $17 \%$. The general anthropometric characteristics of the studied group are presented in table 1.

Tab.1. General anthropometric characteristics of military aviation personnel ( $\mathrm{N}=498)$.

\begin{tabular}{lcc}
\hline Variables & $\mathbf{X} \pm \mathbf{S D}$ & Min - Max \\
\hline Age [years] & $36.3 \pm 8.5$ & $19-59$ \\
\hline Body weight $[\mathrm{kg}]$ & $84.2 \pm 13.6$ & $46.5-136$ \\
\hline Height $[\mathrm{cm}]$ & $177.7 \pm 6.23$ & $157-196$ \\
\hline BMI $\left[\mathrm{kg} / \mathrm{m}^{2}\right]$ & $26.6 \pm 3.79$ & $17.5-43.9$ \\
\hline
\end{tabular}

X - mean, SD - standard deviation

The majority of the surveyed military aviation personnel had a good (45\%) and sufficient (44\%) level of food knowledge (fig. 3).

The level of nutritional knowledge depended significantly on the age and education of the respondents $(p<0.001)$. Younger respondents and those with higher education were characterized by a higher level of nutritional knowledge (tab. 2). In the group of the surveyed Air Force soldiers, military pilots showed the highest level of nutritional knowledge $(p<0.001)$. The lowest level of knowledge was recorded among SIL specialists, who answered 17 out of 32 questions correctly, on average. The analysis of the data did not re- veal any significant differences between the body mass index (BMI) of the respondents and the level of their nutritional knowledge ( $p>0.05$ ). A detailed description of the level of knowledge of the surveyed soldiers depending on their education, age, occupation and BMI is presented in table 2 .

Tab. 2. Characteristics of the level of knowledge of the surveyed soldiers depending on their education, age, occupation and BMI index.

\begin{tabular}{|c|c|c|}
\hline Variables & $\begin{array}{l}\text { Sum of po } \\
\text { from the n } \\
\text { knowledg }\end{array}$ & $\begin{array}{l}\text { obtained } \\
\text { itional } \\
\text { st }\end{array}$ \\
\hline Education & $\mathrm{X} \pm \mathrm{SD}$ & $\mathrm{p}$ \\
\hline Medium & $17.4 \pm 5.2$ & \multirow{2}{*}{$<0.001^{*}$} \\
\hline Higher & $20.3 \pm 4.3$ & \\
\hline \multicolumn{3}{|l|}{ Age } \\
\hline Up to 39 years old & $19.5 \pm 5.0$ & \multirow{2}{*}{$0.011^{*}$} \\
\hline From 40 years & $18.5 \pm 4.6$ & \\
\hline \multicolumn{3}{|l|}{ Occupation } \\
\hline Pilots & $21.0 \pm 4.0$ & \multirow{2}{*}{$<0.001^{*}$} \\
\hline Other aviation personnel & $18.3 \pm 5.0$ & \\
\hline \multicolumn{3}{|c|}{ Nutrition status assessment on the basis of BMI } \\
\hline Standard & $19.7 \pm 5.0$ & \multirow{3}{*}{$0.087^{* *}$} \\
\hline Overweight & $18.9 \pm 4.9$ & \\
\hline Obesity & $18.8 \pm 4.5$ & \\
\hline $\begin{array}{l}\text { X - mean, SD - standar } \\
\text { ** - ANOVA Kruskala- }\end{array}$ & Whitney t & result, \\
\hline
\end{tabular}

Table 3 presents the average frequency of consumption of selected food products and dietary supplements among the studied group of military aviation personnel depending on their level of nutritional knowledge. The analysis of the data shows that the most frequent consumption was for fruit and vegetables and the least frequent

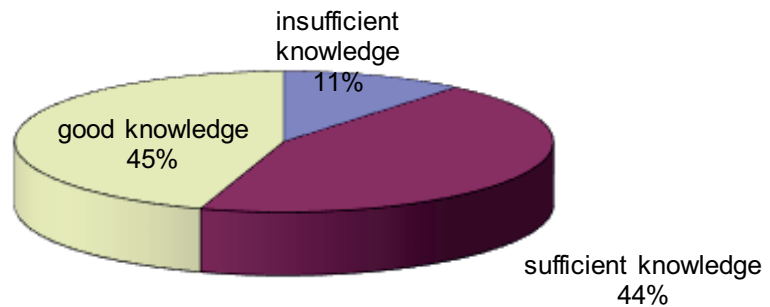

Fig. 3. Characteristics of the nutritional knowledge of military aviation personnel. 
for energy drinks. The level of nutritional knowledge significantly differentiated the frequency of consumption of milk and natural dairy drinks, cottage cheese, eggs and egg dishes, wholemeal bread, coarse groats, oils, margarines, animal fats, fruits, vegetables, grains, fresh pulses and canned legumes, nuts, sausages, poultry and rabbit meat, honey, wine and drinks.

With the increase in the level of nutritional knowledge, the frequency of consumption of milk and natural dairy drinks, cottage cheese, eggs, wholemeal bread, coarse groats, fruit, vegetables, oils, nuts, seeds, poultry and rabbit meat, honey, wine and drinks increased, and the frequency of consumption of margarines in cubes (for roasting, frying), margarines in cups (for spreading), animal fats (e.g. lard, pork fat), sausage products decreased.

There were no statistically significant differences in the frequency of consumption of sugar, sweetened milk drinks, flavoured cottage cheese, cheese (yellow, mould), light bread, fine groats, potatoes, butter, high-quality cured meats, fish, fruit and vegetable juices, energy drinks, sweetened drinks and beer, taking into account the level of respondents' knowledge.

In the group of dietary supplements, vitamin, mineral and vitamin-mineral preparations were significantly more frequently consumed by soldiers with good nutritional knowledge than by those with insufficient knowledge. In the case of the other analysed supplements, no significant differences were found in the frequency of consumption depending on the level of nutritional knowledge of the respondents (tab. 2). However, it was observed that more than $40 \%$ of respondents, regardless of their nutritional knowledge, have never used supplementation with omega-3 or omega- 6 fatty acids. Slimming preparations were the least frequently consumed by the study group, regardless of the level of their nutritional knowledge (tab.3).

Tab. 3. Frequency of consumption of food products, dishes and dietary supplements by military aviation personnel depending on their nutritional knowledge.

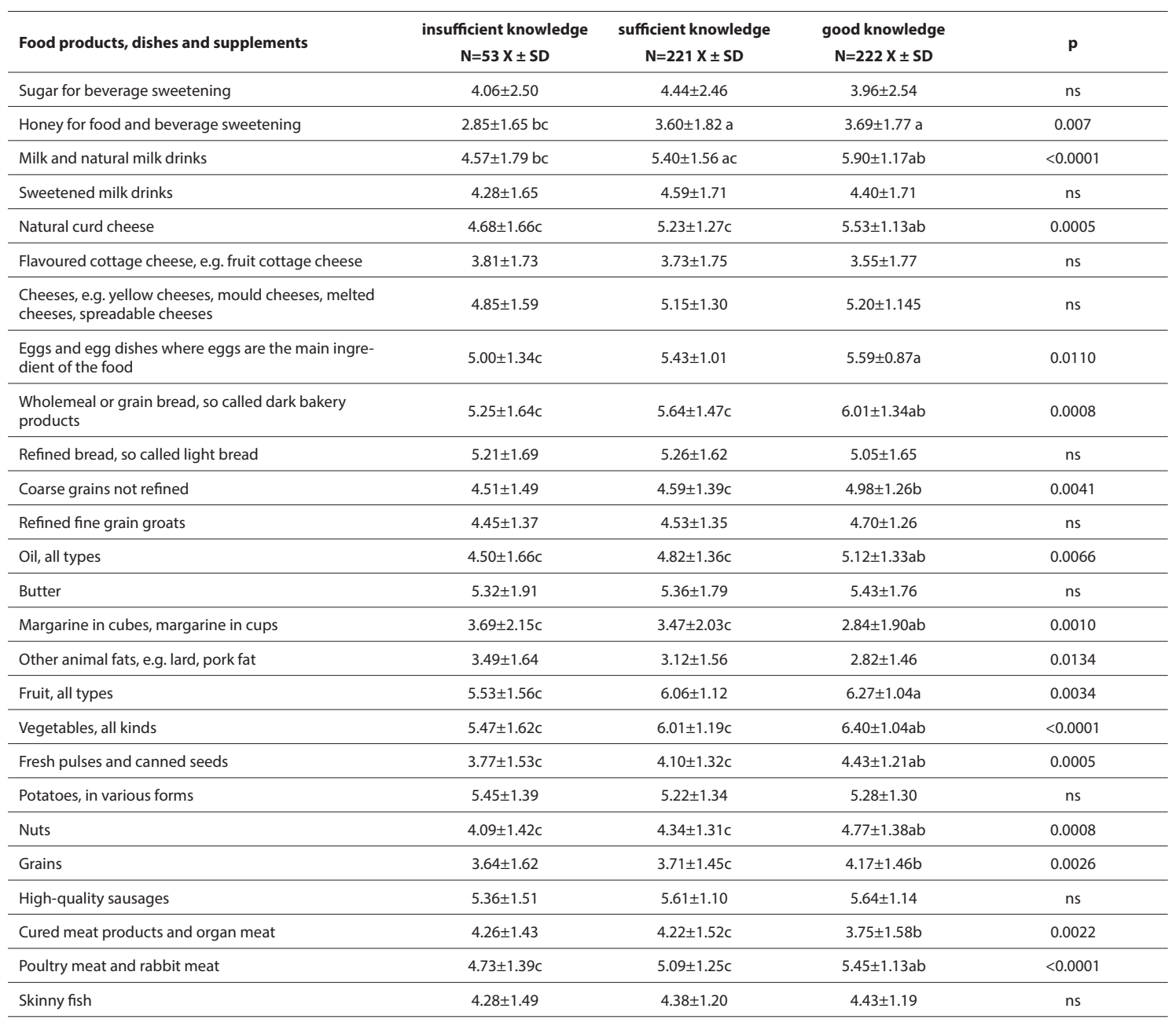


Original Article

\begin{tabular}{|c|c|c|c|c|}
\hline Fatty fish & $3.98 \pm 1.54$ & $4.09 \pm 1.27$ & $4.21 \pm 1.31$ & ns \\
\hline Fruit juices and fruit nectars & $4.45 \pm 1.62$ & $4.65 \pm 1.56$ & $4.77 \pm 1.57$ & ns \\
\hline Vegetable and fruit and vegetable juices & $4.13 \pm 1.66$ & $4.40 \pm 1.45$ & $4.21 \pm 1.49$ & ns \\
\hline Beer & $3.85 \pm 1.55$ & $4.16 \pm 1.48$ & $3.92 \pm 1.38$ & ns \\
\hline Wine and drinks & $2.83 \pm 1.57 \mathrm{bc}$ & $3.33 \pm 1.45 a$ & $3.55 \pm 1.37 a$ & 0.0026 \\
\hline Vodka and spirits & $3.02 \pm 1.62$ & $3.06 \pm 1.25$ & $3.04 \pm 1.25$ & ns \\
\hline Vitamin preparations & $2.26 \pm 1.75 c$ & $3.01 \pm 2.07$ & $3.50 \pm 2.17 a$ & 0.0004 \\
\hline Omega-3 fatty acids & $2.29 \pm 1.67$ & $2.63 \pm 1.82$ & $2.62 \pm 1.81$ & ns \\
\hline Omega- 6 fatty acids & $2.39 \pm 1.67$ & $2.50 \pm 1.71$ & $2.48 \pm 1.77$ & ns \\
\hline $\begin{array}{l}\text { Preparations intended for use by persons involved in } \\
\text { sport }\end{array}$ & $2.46 \pm 1.65$ & $2.61 \pm 1.94$ & $2.85 \pm 2.12$ & ns \\
\hline $\begin{array}{l}\text { Preparations accelerating the regeneration of joint } \\
\text { cartilage and used in injuries to the locomotor system }\end{array}$ & $2.08 \pm 1.67$ & $1.90 \pm 1.57$ & $2.02 \pm 1.72$ & ns \\
\hline Slimming preparations & $1.51 \pm 1.24$ & $1.35 \pm 0.94$ & $1.28 \pm 0.91$ & ns \\
\hline $\begin{array}{l}\text { Preparations used to improve the condition of the skin, } \\
\text { hair or nails }\end{array}$ & $1.71 \pm 1.43$ & $1.64 \pm 1.33$ & $1.56 \pm 1.33$ & ns \\
\hline
\end{tabular}

$\mathrm{N}$ - group size, $\mathrm{X}$ - mean, SD - standard deviation, ns - not significant

* $a, b$ - different letters denotes significant differences, ns - no statistically significant difference, where: 1- never or almost never, 2 - once a quar-

ter or less, 3 - once a month or less, 4 - several times a month, 5 - once a week, 6 - several times a week, 7 - everyday, 8 - several times a day

A detailed breakdown of the frequency of consumption of food products and food supplements (by 8 frequency categories) by military aviation personnel, regardless of their level of nutritional knowledge, is given in table 4 . The frequency of consumption of wholegrain bread, milk and milk products, fish, dry pulses, fruit and vegetables was found to be too low. When evaluating the consumption of milk and milk products, it was observed that their consumption was at a very differentiated level. Respondents most often consumed them once or several times a week. Respondents in this group of products most often chose yellow cheese, mould cheese, spreadable cheese, milk and natural milk drinks.

Tab. 4. Percentage of responses on the frequency of consumption of food products, beverages, dietary supplements provided by military aviation personnel $(\mathrm{N}=498)$.

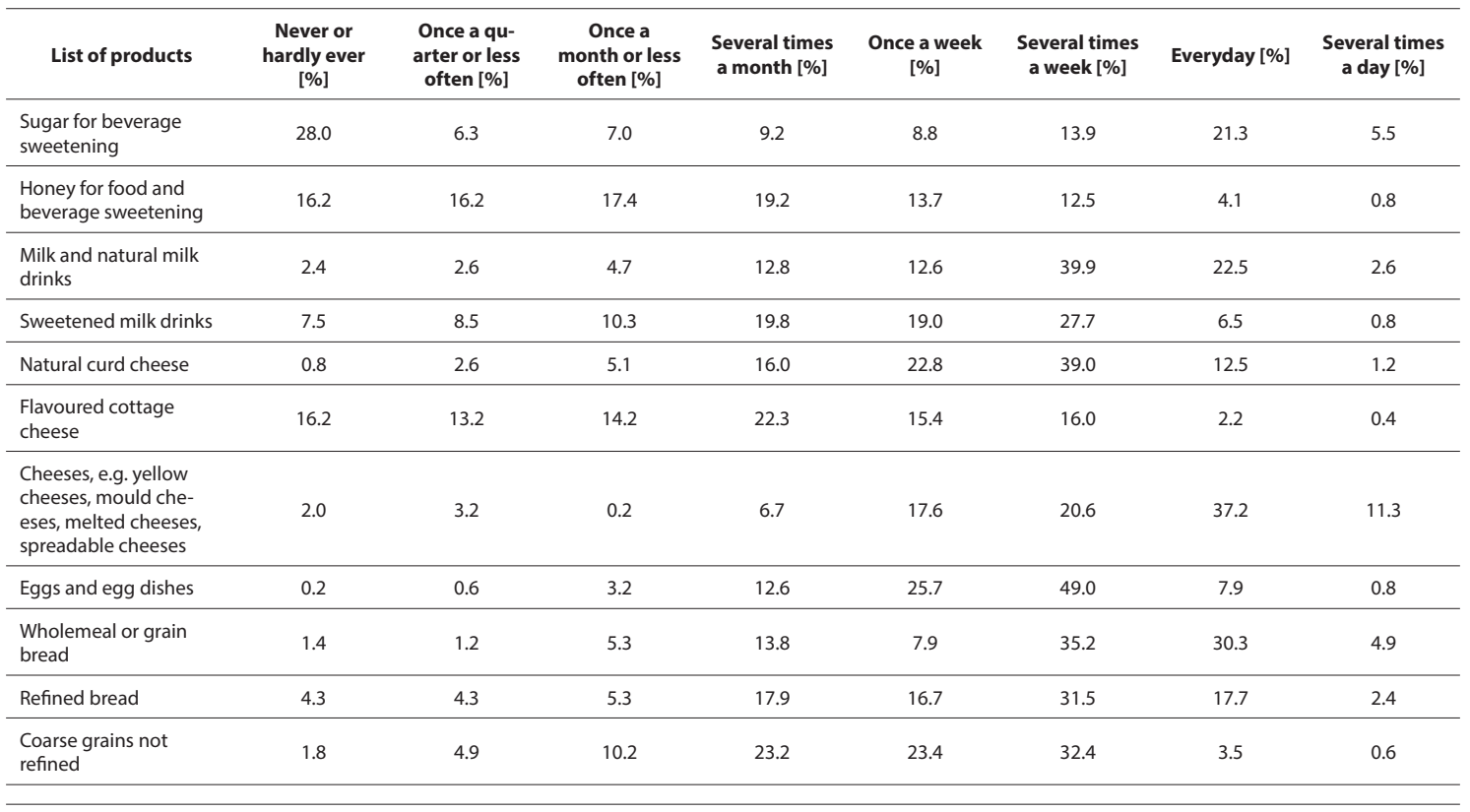


Gaździńska A. et al. - Assessment of the frequency...

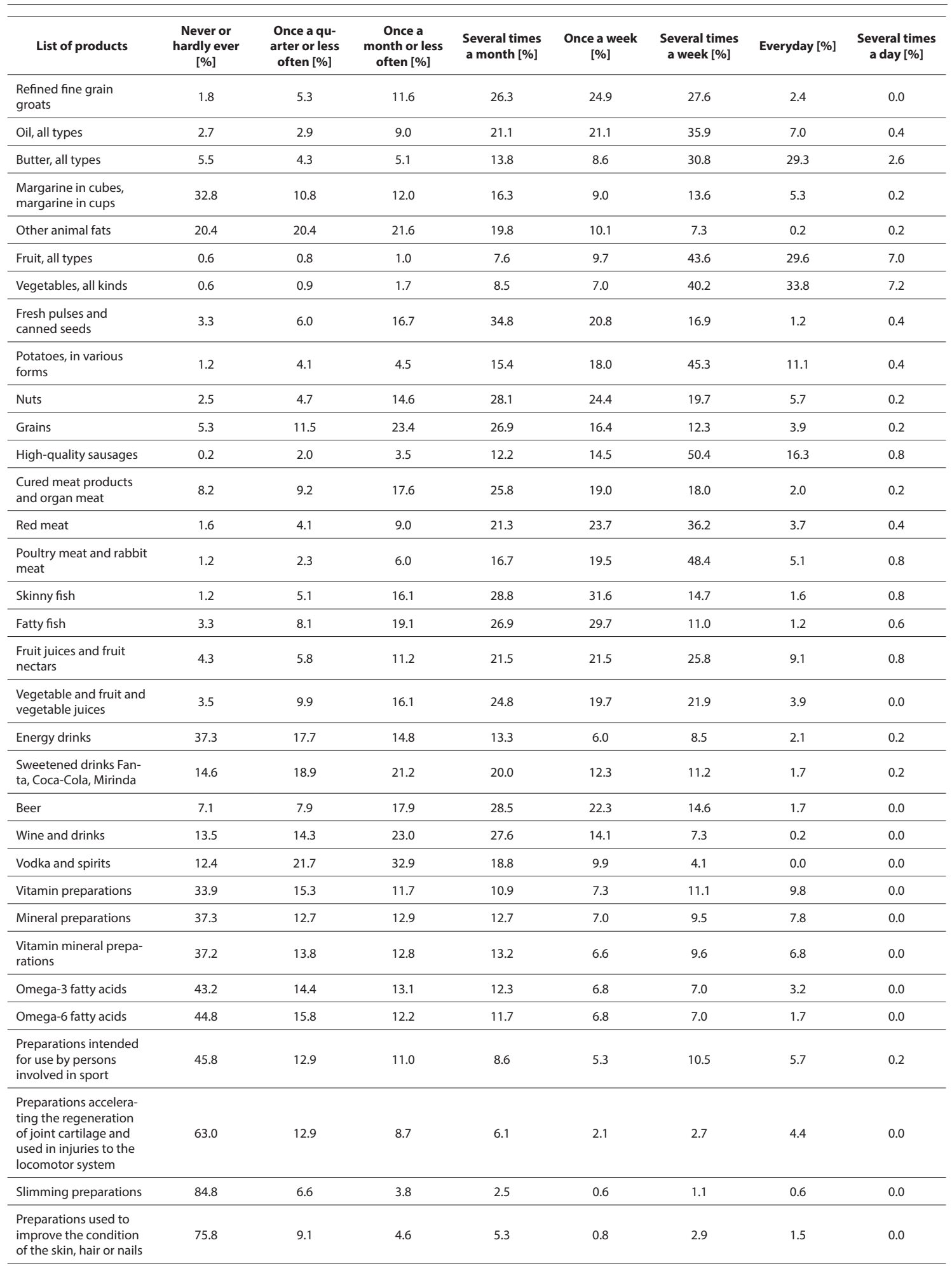

\section{DISCUSSION}

Nutritional knowledge and the resulting diet are important factors affecting human health. The conducted research has shown a varied level of nutritional knowledge among military aviation personnel. Similar observations were made by other authors researching the nutritional knowledge of GROM Special Forces soldiers [2]. Whereas Kler and Bertrandt [22], in the course of assessing the level of nutritional knowledge among the soldiers of the Army of Territorial Defence, stated its exceptionally low level. 
The results obtained in this study confirm earlier reports of other authors, indicating an increase in the level of nutritional knowledge and education [32]. Kullena et al., in the course of evaluating the level of nutritional knowledge among 1295 soldiers of the Australian Army, showed a positive correlation with age and female gender in addition to education [26]. Similar results were obtained among US Navy soldiers, where the knowledge of nutrition was higher among older respondents, better educated people, women, as well as overweight people [43]. Our own research did not confirm the influence of the degree of overweight on the level of nutritional knowledge in the studied group. However, a higher level of nutritional knowledge was found in the younger age group, and not in the older one, as it was found in the aforementioned studies [43].

In nutritional epidemiology, the method of testing the frequency of food consumption is considered a very valuable measurement tool $[7,15,42]$. Among the factors that determine food choice, education-related factors, but also the type of work performed, are important. Education affects the level and structure of consumption in two ways: on the one hand, it develops needs and on the other, it enables them to be met. Persons with a relatively higher level of education to a greater extent feel the needs of a higher level and strive to satisfy them. Moreover, they have a greater knowledge of available products and possibilities of their use, and are characterized by higher requirements towards the purchased products [47]. People with a lower level of education concentrate mainly on satisfying basic needs, in their case the choices made are mainly determined by the basic functions of the product and its price [47].

On the basis of the analysis of own results obtained from the frequency of consumption questionnaire, it can be concluded that the diet of the majority of the studied military aviation personnel differed from the recommended model of nutrition. Experts recommend that a well-balanced and varied diet should include fruit and vegetables every day [29]. The World Health Organization (WHO) postulates that their daily intake should be $400 \mathrm{~g}$, excluding potatoes and other starch-containing tubers [10]. Scientific studies prove that increased consumption of fruit, vegetables and their preserves plays a beneficial role in the prevention of chronic diseases, including civilization diseases [37,35]. Fruit, vegetables and their preserves are a source of valuable and essential components, such as vitamins, minerals, dietary fiber, flavonoid compounds, phytoestrogens, pec- tins, easily assimilable sugars and organic acids $[29,33]$. Recent reports have shown that consuming 1-3 servings of these products reduces the risk of cancer, heart attack and stroke by $14 \%$. From 5 to 7 portions of fruit and vegetables decrease it by $36 \%$, and over 7 portions decrease it by $42 \%$ [18]. Although fruit and vegetables were the products most frequently consumed by the respondents, only $30 \%$ of soldiers declared their daily consumption. The majority of respondents (44\%) declared that they consumed these products several times a week (tab. 3).

When evaluating the consumption of milk and milk products in our study, we observed that their consumption was at very diversified levels. Persons with good nutritional knowledge consumed milk and natural curd significantly more often than persons with insufficient nutritional knowledge $(p<0.001)$.

A team of experts from scientific societies and institutes dealing with nutrition and the Human Nutrition Committee of the Polish Academy of Sciences and the Polish Society of Nutrition Sciences recommends that adults consume at least two portions of milk and milk products per day. At the same time, the Food and Nutrition Institute strongly emphasises that there is no reliable scientific evidence from epidemiological studies that recommended consumption of dairy products in such quantities may have negative health consequences.

Milk and milk products are among the most valuable products. They have a varied composition, provide the necessary building and regulating components, so important from the point of view of combat readiness. These are products that provide complete protein and easily assimilable calcium, which is extremely valuable in the diet [5]. In Poland, none of the demographic groups meets all-day demand for calcium. The average daily supply of this element in diets of adults ranges from 600-700mg [41].

Based on the studies performed, it can be concluded that the frequency of fish consumption by military aviation personnel is not consistent with the dietary recommendations to consume fish at least twice a week [30]. The recommended amount of fatty fish was consumed by $11 \%$ of the respondents. Most (30\%) ate fish once a week. $11 \%$ of the respondents consumed fatty fish once a quarter or less frequently. The situation with the frequency of eating lean fish such as cod, Alaska pollock or perch, where $15 \%$ of the respondents consumed them several times a week and 32\% once a week, was better. Studies have not shown 
that low fish intake translates into higher frequency of supplementation with omega-3 fatty acids, one of the main sources of which is fish.

Dietary supplements are often used by soldiers of various armies [23,34]. Among Special Forces soldiers, Lepionka et al. recorded the use of dietary supplements at the level of 50.5\% [27]. Interestingly, only $6 \%$ of the respondents consumed dietary supplements in this group on doctor's recommendation. Frequent use of supplements was also shown among land forces soldiers and candidates for the Air Force Officer Academy in Dęblin, currently the Aviation Military Academy $[39,13]$.

Our research didn't confirm that. Military aviation personnel consumed them sporadically, usually 3 times a month or less frequently. Daily vitamin preparations were consumed by only $10 \%$ of respondents, mineral preparations by $8 \%$, preparations for sportsmen - $6 \%$, and omega-3 fatty acids by only $3 \%$ of respondents. In own studies, the majority of respondents were men, however according to the studies by Kozłowski et al., women, especially those with higher education, use dietary supplements much more often. The reason why women most often used dietary supplements was the desire to lose weight $(31.5 \%$ of respondents) and the beneficial effect on hair, nails and skin (29.6\% of respondents). Men, on the other hand, most often used dietary supplements because they wanted to increase immunity $(38.9 \%$ of respondents) [13]. In our own research it was shown that vitamin preparations were consumed most often and slimming preparations were the least frequently used ones, which was certainly dictated by the small number of women in the study group.
The results of the study presented in this paper indicate abnormal nutritional behavior among military aviation personnel, which may contribute to the development of diet-related diseases, including overweight and obesity. Poor diet, associated with the inadequate quantity and structure of food consumed, is one of the most important risk factors for the development of these diseases. Meanwhile, education in the field of proper nutrition is a way of improving human health potential and a form of prevention of many civilization diseases. Much progress in nutrition education has been made possible by the development of research on food and nutritional behaviour, giving rise to increased knowledge of the role of nutrition in human health. Therefore, it seems that there is a need for continuous educational activities aimed at promoting the principles of rational nutrition among military aviation personnel.

\section{CONCLUSIONS}

1. On the basis of the assessment of the frequency of consumption of products, a number of abnormalities were found among the majority of the surveyed soldiers of military aviation personnel.

2. The results obtained confirm that a higher level of nutritional knowledge promotes healthy eating habits among the Air Force soldiers.

3. Food education is essential, especially among soldiers in the older age group and ground flying personnel.

\section{AUTHORS' DECLARATION:}

Study Design: Agata Gaździńska, Marta Turczyńska, Paweł Jagielski. Data Collection: Agata Gaździńska, Marta Turczyńska, Paweł Jagielski. Manuscript preparation: Agata Gaździńska, Marta Turczyńska, Paweł Jagielski. Funds Collection: Agata Gaździńska, Marta Turczyńska, Paweł Jagielski. The Authors declare that there is no conflict of interest. 


\section{REFERENCES}

1. Andrews MC, Itsiopoulos C. Room for improvment in nutrition knowledge and dietary intake of football (soccer) players in Australia. Int J Sport Nutr Exerc Metab 2016; 26(1):55-64.

2. Bębnowicz A, Bertrandt B, Kler P, Bertrandt J. Ocena poziomu wiedzy żywieniowej żołnierzy pełniących służbę w polskiej jednostce Wojsk Specjalnych „GROM”, Probl Hig Epidemiol 2015; 96(4):782-784.

3. Birkenhead KL, Slater G. A review of factors influencing athletes` food choices. Sports Medicine 2015; 45(11):1511-1522.

4. Brzozowska A, Roszkowski W, Pietruszka B, Kałuża J. Witaminy i składniki mineralne jako suplementy diety. Żywność Nauka Technologia Jakość 2005; 4(45) Supl.: 5-16.

5. Całyniuk B, Zołoteńka-Synowiec M, Grochowska-Niedworok E, Misiarz M, Malczyk E, Filarska M, Kutnohorsk J. Częstotliwość spożycia mleka i produktów mlecznych przez młodzież w wieku 16-18 lat, Probl Hig Epidemiol 2015; 96(1):240-244.

6. Czarnocińska J, Zaborowicz K, Galiński G, Kaźmierczak P, Górska K, Durczewski P. Ocena częstotliwości spożycia produktów spożywczych przez studentów zależnie od ich wiedzy żywieniowej. Probl Hig Epidemiol 2016; 97(4):348-351.

7. Drewnowski A: Diet image: a new perspective on the food-frequency-questionnaire. Nutr Rev 2001; 59:370-374.

8. Duda G, Różycka-Cała K, Przysławski J.Sposób żywienia a wybrane wskaźniki stanu odżywienia osób w wieku podeszłym. Nowa Med. 2000; 12:17 PM-18.

9. Duda G, Wichura-Demska A. Wpływ wybranych czynników socjodemograficznych na poziom wiedzy osób zdrowych dotyczącej racjonalnego żywienia, Nowiny Lekarskie 2008; 77(4):290-293.

10. European Action Plan for Food and Nutrition 2007-2012. WHO, Copenhagen 2008.

11. Gaździńska A, Baran P, Skibniewski F, Truszczyński O, Gaździński S, Wyleżoł M. Częstość występowania nadwagi i otyłości u studentów lotniczej uczelni wojskowej a poziom ich aktywności fizycznej, Medycyna Pracy 2015; 66(5):653-660.

12. Gaździńska A, Wójcik R, Janewicz M, Binder M, Wyleżoł M, Gaździński S. Excess Body Weight as a Risk Factor to Well-being and Performance of Flight Personnel: Potential Strategies of Prevention. Pol J Aviat Med Psychol 2014; 20(4):27-36.

13. Gaździńska A. Suplementacja składnikami mineralnymi, witaminami i napojami energetyzującymi diety kandydatów do Wyższej Szkoły Oficerskiej Sił Powietrznych. Żyw Człow Metab 2007; 34(1-2):84-90.

14. Gertig H, Gawęcki J. Podstawy nauki o żywieniu, T. 1, Wydawnictwo Naukowe PWN, Warszawa 2008.

15. Gibson RS. Principles of nutritional assessment. Oxford Uniwersity Press, New York, 1990:97-136.

16. Gronowska-Senger A. Błędy żywieniowe stanowiące ryzyko dla zdrowia w Polsce. Żywn Nauka Technol Jakość 2001; 4(29), Supl.:50-61.

17. Gronowska-Senger A. Żywienie, styl życia a zdrowie Polaków. Żywienie Człowieka i Metabolizm 2007; 34:12-20.

18. Gwóźdź E, Gębczyński P. Prozdrowotne właściwości owoców, warzyw i ich przetworów, Postępy Fitoterapii 2015; 4:268-271.

19. Jarosz M, Ciok J. Suplementy diety a zdrowie: porady lekarzy i dietetyków. Wydawnictwo Lekarskie PZWL, Warszawa, 2015.

20. Jarosz M. (red.) Otyłość, żywienie, aktywność fizyczna, zdrowie Polaków. Instytut Żywności i Żywienia, Warszawa, 2006.

21. Jeżewska-Zychowicz M. Zachowania żywieniowe i ich uwarunkowania. SGGW, Warszawa 2007.

22. Kler P, Bertrandt J. Ocena jakości wiedzy żywieniowej żołnierzy Wojsk Obrony Terytorialnej jako element bezpieczeństwa żywienia, Problemy Jakości 2018; 50(9):21-26.

23. Knapik JJ, Steelman RA, Hoedebecke SS, Farina EK, Austin KG, Lieberman HR. A systematic review and meta-analysis on the prevalence of dietary supplement use by military personnel. BMC Complement Altern Med 2014; 14(1):143.

24. Kozłowski P, Kozłowska M, Kozłowska K. Evaluation of the prevalence of dietary supplement consumption in selected group of young adults. Journal of Education, Health and Sport 2017; 7(8):106-113.

25. Krejpcio Z, Skwarek K, Hyżyk AK, Dyba S. Ocena powszechności spożycia suplementów diety w wybranej grupie osób aktywnych sportowo. Probl Hig Epidemiol 2011; 92:935-938.

26. Kullen CJ, Iredale L, Prvan T, Connor TO. Evaluation of General Nutrition Knowledge in Australian Military Personnel, Journal of the Academy of Nutrition and Dietetics 2016; 116(2):251-258.

27. Lepionka T, Anyżewska A, Łakomy R, Szarska E, Maculewicz E, Tomczak A, Bertrandt J. Stosowanie suplementów diety a częstotliwość spożycia wybranych grup produktów przez żołnierzy Wojsk Specjalnych, Bromat Chem Toksykol 2019; 52(2):126131.

28. Lidia Wądołowska. Walidacja kwestionariusza częstotliwości spożycia żywności - FFQ. ocena powtarzalności. Bromat Chem Toksykol 2005; 18(1):27-33.

29. Markowski J, Płocharski W, Pytasz U. Owoce, warzywa, soki - ich kaloryczność i wartość odżywcza na tle zapotrzebowania na energię i składniki odżywcze. Cz. 1. Kaloryczność i mit o wpływie na otyłość. Przem Ferm Owoc-Warzyw 2012; 9:24-27. 
30. Mozaffarian D. Cardiac Benefits of Fish Consumption May Depend on the Type of Fish Meal Consumed: The Cardiovascular Health Study. Circulation 2003; 107(10):1372-1377.

31. Oblacińska A, Tabak I. (red.). Jak pomóc otyłemu nastolatkowi? Rola pielęgniarki szkolnej i nauczyciela wychowania fizycznego we wspieraniu młodzieży z nadwagą i otyłością. Poradnik dla pielęgniarek szkolnych i nauczycieli wychowania fizycznego w gimnazjach. Warszawa: Instytut Matki i Dziecka 2006.

32. Ostachowska-Gąsior A, Krzeszowska-Rosiek T, Górska S. Ocena wiedzy żywieniowej osób o wysokiej aktywności fizycznej uczęszczających do klubów fitness. Probl Hig Epidemiol 2014; 95(4):969-974.

33. Oszmiański J. Soki owocowe o wysokiej aktywności biologicznej. Przem Ferm Owoc-Warzyw 2007; 4:12-16.

34. Paisley RD. Nutritional and sports supplement use among deployed U.S. Army soldiers in a remote, austere combat outpost in eastern Afghanistan. Mil Med 2015; 180(4): 391-401.

35. Płocharski W, Ciok J, Markowski J. Owoce, warzywa, soki - ich kaloryczność i wartość odżywcza na tle zapotrzebowania na energię i składniki odżywcze. Cz. 3. Możliwość poprawy wartości odżywczej i zdrowotnej soków i ich rynkowego wizerunku a znakowanie produktów. Przem Ferm Owoc-Warzyw 2013; 2:18-22.

36. Poręba R, Gać P, Zawadzki M. i wsp. Styl życia i czynniki ryzyka chorób układu krążenia wśród studentów uczelni Wrocławia. Pol Arch Med Wewn 2008; 118(3):1-9.

37. Rimm EB, Ascherio A, Giovannuci E. Vegetable, fruit and cereal fiber intake and risk of coronary heart disease among men. J Am Med Assoc 1996; 275:447-51.

38. Rodziewicz-Gruhn J, Połacik J. Diagnoza nawyków żywieniowych studentów różnych kierunków studiów w Akademii im. Jana Długosza w Częstochowie. PNAJD Kult Fiz 2013; 12(2):173-191.

39. Rozmysł E, Kłos A, Bertrandt J, Schlegel-Zawadzka M.:Ocena zjawiska indywidualnej suplementacji diety witaminami i składnikami mineralnymi wśród żołnierzy pełniących zasadniczą służbę wojskową. Żyw Człow Metab, 2003; 30(1-2):392-397.

40. Sobolewska A, Sztanke M, Boguszewska-Czubara A i wsp. Influence of physical activity and nutritional habits on occurence of metabolic diseases. Zdr Publ 2007; 117(4):419-424.

41. Szeleszczuk Ł, Kuras M. Znaczenie wapnia w metabolizmie człowieka i czynniki wpływające na jego biodostępność w diecie. Biul Wydz Farm. WUM, 2014; 3:16-22.

42. Thomas B. Manuał of dietetic practice. Blackwell Science, UK, Oxford, 3rd ed., 2001; 30-37.

43. Trent LK. Nutrition knowledge of active-duty Navy personnel. J AM Diet Assoc 1992; 92(6):724-728.

44. World Health Organization: Obesity: Preventing and managing the global epidemic. Report of a WHO consultation. WHO Technical Report Series 894. WHO, Genewa, 2000.

45. Zaborowicz K, Czarnocińska J, Galiński G, et al. Evaluation of selected dietary behaviours of students according to gender and nutritional knowledge. Rocz PZH 2016; 67(1):45-50.

46. Zalewska M, Maciorkowska E. Rola edukacji żywieniowej w populacji dzieci i młodzieży. Medycyna Ogólna i Nauki o Zdrowiu 2013; 19(3):375-378.

47. Żelazna K, Kowalczuk I, Mikuta B. Ekonomika konsumpcji, SGGW, Warszawa, 2002.

Cite this article as: Gaździńska A, Turczyńska M, Jagielski P. Assessment Of The Frequency Of Food Products Consumption And Dietary Supplements By Military Aviation Personnel Depending On Their Nutritional Knowledge. Pol J Aviat Med Bioeng Psychol 2019; 25(2): 13-23. DOI: 10.13174/pjambp.15.12.2020.02 